\title{
Analysis of Creative Thinking Skills and Student Learning Motivation in Solving Problems
}

\author{
Novferma $^{1}$, Husni Sabil ${ }^{2}$, Febbry Romundza ${ }^{3}$ \\ \{novfermaa@gmail.com ${ }^{1}$, sabilmath@gmail.com ${ }^{2}$, febbri_romundza@yahoo.com ${ }^{3}$ \} \\ 1,2Jambi University, ${ }^{3}$ Jakarta State University
}

\begin{abstract}
This study aims to see whether there is a relationship between student learning motivation with students' creative thinking skills. This research is a survey research using a qualitative approach. The subjects of this study were 34 high school students. The instruments used in data collection were tests of creative thinking skills, motivational questionnaires, and interview guides. The results showed that there is a relationship between students who have high motivation, creative thinking skills are also high, and vice versa. Data obtained that 5.9\% of students who have high motivation, $32.4 \%$ of students have moderate motivation, $58.8 \%$ of students who have low motivation, and $2.94 \%$ of students who have very low motivation. While students' creative thinking skills found $29.4 \%$ of students in the fluency stage, $35.3 \%$ of students at the flexibility stage, and $23.5 \%$ of students at the Novelty stage in solving math problems were given. So, it can be concluded the need for efforts made by the teacher is to design a Math Teaching Kit that can facilitate students' motivation and creative thinking skills.
\end{abstract}

Keywords: Creativity Thinking Skills, Motivation, Mathematics Learning

\section{Introduction}

Mathematics is one of the fields of science that has a great influence on daily life. The great influence of mathematics can be seen in so many aspects of daily life that use the basic concepts of mathematics, such as in calculating the amount of money we have, calculating the amount of the price of the goods we buy, estimating how much building material is needed to make a building construction, and others. In addition, mathematics is a part of science that is useful as a tool to develop other sciences. Understanding a mathematical concept becomes very important so that mathematics can be applied in other sciences as well as possible. One application of mathematics that is very beneficial is the development of information and communication technology, for example, to develop programming languages, and data structures which are examples of the application of mathematical logic. Kids must be introduced and learn mathematics from an early age in order to equip them in developing knowledge and skills with the skill to think logically, analytically, systematically, critically, and creatively. Kids also must be able to apply mathematics in everyday life. High school students must have high-level thinking so that the objectives of the learning delivered can be achieved and implemented well [1].

The learning objectives of mathematics in the Class X Mathematics Teacher's Book are as follows: (1) Understanding mathematical concepts includes competence in explaining inter-conceptual relationships and using concepts and algorithm flexibly, accurately, efficiently, and precisely in problem-solving; (2) Communicating ideas, reasoning and being able to compile mathematical evidence using complete sentences, symbols, tables, diagrams, or other media to clarify the situation or problem; and others [2]. The learning objectives encourage students to have a high level thinking skill, to find and solve the problems given. Thinking includes the transfer of information to the brain or memory and includes manipulation. When we are thinking, we can form a concept, find reasons, think critically and creatively, make decisions, and solve the problems given. One of these thinking abilities is the creative thinking skill. The creative thinking skill is the skill to think that involves cognitive processes [3]. Cognitive processes or cognitive skills are more related to the skill to find problems and identify relevant and non-relevant data [4]. Creative thinking is a habit of thinking that is trained by paying attention to intuition and imagination, proposing new ideas that could not have been 
predicted before [5]. Creativity always creates new products by combining knowledge from various aspects of science so that the process of scientific thinking results form a solution to a problem so it is clear that creativity can influence a successful learning process [6].

The indicators of creative thinking, namely: 1) Fluency (the skill to produce many ideas that come out of someone's thoughts appropriately), 2) Flexibility (the skill to produce a number of ideas), and 3) Novelty (renewal of ideas created) [7 ] However, in real life, high school students have low creative thinking skills, where most students cannot find solutions to solve the problems given during the learning process in class. This is also supported by the TIMSS survey results on the mathematics learning process, viewed from the reasoning, application, and knowledge aspects. The results of the survey conducted by TIMSS show that the skill of Indonesian students is at the lowest cognitive knowing level, with an average score of 378 from a maximum score of 616[8]. Most Indonesian students also have not been able to apply basic knowledge in solving the problems given (Applying), while in reasoning most students have not been able to understand and apply knowledge in complex problems. This happened because learning mathematics in schools has not been focused or emphasized the skill of students. One of these abilities is the creative thinking skill so that the learning objectives of mathematics have not been maximally reached. Even though we know that the creative thinking skill is an skill that is needed by students in the process of learning mathematics [9].

There are several factors that could affect the process of learning mathematics that make students have a low creative thinking skill, these factors are extrinsic and intrinsic factors from the students. One intrinsic factor of students is motivation. Define "motivation is the process where goal-directed activity is instigated and sustained" [10]. The definition explains that motivation is a process in which goals are directed towards ongoing activities. Motivation is the strenth that comes within a person to carry out certain activities to achieve a goal.

The effort to achieve this goal has the same meaning as motivation. An individual who shows more effort is considered to have motivation, while someone who is motivated will also show more effort. Motivation comes from the word motive, which means the strength that comes from within a person, the high motive of students to achieve and avoid failure will respond more to the tasks given by the teacher. Success and appreciation from friends or from the teacher will provide a sense of satisfaction and enhance the skill of students' skill to make efforts because of the learning objectives concerning the needs of the problem; namely the need to do something to learn, the need to achieve results after learning, and the need to overcome learning difficulties [11].

The objectives of this research are 1) to see whether there is a relationship between students 'motivation and students' creative thinking abilities in the mathematics learning process; 2) to analyze students' creative thinking abilities and motivation in the learning process.

\section{Methods}

This research is a survey research with a qualitative approach. The research subjects were 24 high school students with high, medium, and low categories who were all given a motivation questionnaire and a student's creative thinking skill test.

The first stage in this research is to provide a motivational questionnaire. The motivation questionnaire was arranged based on 5 aspects, namely: 1) anxiety, 2) effort, 3) interest, and 4) self-efficacy which then became 5 aspects that were developed into 13 indicators for measuring student motivation. The motivational questionnaire consists of positive and negative items with a total of 30 items/statements. The second phase of research is to provide a test of creative thinking skills. The tests (questions) are in the form of essays so that it is easy to record the students' work in their creative thinking skill. The questions given were 3 essays consisting of 3 indicators of creative thinking skill measurement, namely: 1) Fluency, 2) Flexibility, and 3) Novelty. The third stage of the research is in-depth interviews of the research sample units determined after the first and second stages are completed and the results of student work are checked.

The instruments used in data collection were tests of creative thinking skills, motivational questionnaires, and interview guidelines. The instrument was validated by three experts and was 
declared valid. Students who get a score below 70 (minimum completeness) are categorized as students who have low creative thinking skills.

Data analysis is carried out during and after data collection so that the data obtained is arranged systematically and is more easily interpreted in accordance with the formulation of the problem. The steps in analyzing and interpreting the data are carried out in stages, namely first, collecting and formulating all data obtained from the research. This activity is carried out by: (1) checking the results of student motivation questionnaires in the learning process; (2) examine student test results in solving creative thinking skills questions consist of 1) Fluency, 2) Flexibility, and 3) Novelty. This research uses a student motivation questionnaire consisting of 30 items/statements using 5 Likert scales. The Likert scale used is strongly agree $(=5)$ until strongly disagree $(=1)$. Quantitative data is converted to qualitative data using table 1 as follows: [12].

Table 1. Conversion of Quantitative Data to Qualitative Date

\begin{tabular}{llll}
\hline No & \multicolumn{1}{c}{ Interval } & \multicolumn{1}{c}{ Score $(\mathrm{X})$} & \multicolumn{1}{c}{ Criteria } \\
\hline $\mathbf{1}$ & $\mathrm{Mi}+1,5 \mathrm{Si}<\mathrm{X} \leq \mathrm{Mi}+3 \mathrm{Si}$ & $98<\mathrm{X} \leq 130$ & Very High \\
$\mathbf{2}$ & $\mathrm{Mi}+0,5 \mathrm{Si}<\mathrm{X} \leq \mathrm{Mi}+1,5 \mathrm{Si}$ & $76<\mathrm{X} \leq 98$ & High \\
$\mathbf{3}$ & $\mathrm{Mi}-0,5 \mathrm{Si}<\mathrm{X} \leq \mathrm{Mi}+0,5 \mathrm{Si}$ & $54<\mathrm{X} \leq 76$ & Medium \\
$\mathbf{4}$ & $\mathrm{Mi}-1,5 \mathrm{Si}<\mathrm{X} \leq \mathrm{Mi}-0,5 \mathrm{Si}$ & $33<\mathrm{X} \leq 54$ & Low \\
$\mathbf{5}$ & $\mathrm{Mi}-3 \mathrm{Si}<\mathrm{X} \leq \mathrm{Mi}-1,5 \mathrm{Si}$ & $0<\mathrm{X} \leq 33$ & Very Low \\
\hline
\end{tabular}

\section{Results and Discussion}

In this research, researchers collected information through student motivation questionnaires, creative thinking skills test, and the results of interviews given. Before being given a creative thinking skill test, students' motivation towards learning is first measured, using a questionnaire. The questionnaire consists of 30 items with each item having a score range of 0 to 5 , so the range of motivational scores has a range of 0 to 130 . Data on measuring student motivation is presented in table 2 , as follows:

Table 2. Data Description High School Students' Learning Motivation

\begin{tabular}{|c|c|}
\hline Descriptions & High School \\
\hline Average & 51,2 \\
\hline Highest score possible & 130 \\
\hline Lowest score possible & 30 \\
\hline Highest score achieved by students & 78 \\
\hline Lowest score achieved by students & 33 \\
\hline
\end{tabular}

The frequency and percentage of many students on each criterion of students' mathematics learning motivation is calculated based on a predetermined score range. The frequency distribution and percentage of high school students' mathematics learning motivation is presented in Table 3, as follows:

Table 3. Frequency Distribution and Percentage of High School Students' Learning Motivation

\begin{tabular}{|c|c|c|c|}
\hline \multirow{2}{*}{ Score $(\mathrm{X})$} & \multirow{2}{*}{ Criteria } & f & High Shool \\
\cline { 3 - 4 } & & 0 & 0 \\
\hline $98<\mathrm{X} \leq 130$ & Very High & 2 & 5,9 \\
\hline $76<\mathrm{X} \leq 98$ & High & 11 & 32,4 \\
\hline $54<\mathrm{X} \leq 76$ & Moderate & 20 & 58,8 \\
\hline $33<\mathrm{X} \leq 54$ & Low & 1 & 2,94 \\
\hline $0<\mathrm{X} \leq 33$ & Very Low & \\
\hline
\end{tabular}

Table 3 shows that the scores of high school students' mathematics learning motivation are spread over the low criteria. The number of students in high school who have a motivation to learn, on very high 
criteria is $0(0 \%)$ of 34 students; high criteria is $2(5.9 \%)$; moderate criteria is $11(32.4 \%)$; low criteria is $20(58.8 \%)$; and very low criteria is $1(2.94 \%)$. The average of high school student motivation to learn mathematics is 50.9, that means that students' learning motivation in mathematics is still relatively low. Creative thinking skills test results were given to 34 students who were used to obtain data on students' skill in the mathematics learning process. tests (essay questions) given as many as 3 questions consisting of indicators: 1) Fluency, 2) Flexibility, and 3) Novelty. In entirety, it can be seen from the results of the student answers from all research subjects in table 4, as follows:

Table 4. Results of Answers to the Test of Creative Thinking skill in Completing 3 Items.

\begin{tabular}{|l|c|c|c|c|c|c|}
\hline \multirow{2}{*}{$\begin{array}{c}\text { Types of } \\
\text { Answers }\end{array}$} & \multicolumn{6}{|c|}{ Students' Answer } \\
\cline { 2 - 7 } & Fluency & $\begin{array}{l}\text { Persentase } \\
(\%)\end{array}$ & Flexibility & Persentase (\%) & Novelty & $\begin{array}{l}\text { Persentase } \\
(\%)\end{array}$ \\
\hline Correct (B) & 0 & 0 & 0 & 0 & 0 & 0 \\
\hline $\begin{array}{l}\text { Correct but } \\
\text { Incomplete } \\
\text { (BL) }\end{array}$ & 3 & 8,8 & 3 & 14,7 & 1 & 2,9 \\
\hline $\begin{array}{l}\text { Not } \\
\text { Completed } \\
\text { (TS) }\end{array}$ & 10 & 29,4 & 8 & 23,5 & 7 & 20,6 \\
\hline $\begin{array}{l}\text { An Error } \\
\begin{array}{l}\text { Occurred } \\
\text { (AK) }\end{array}\end{array}$ & 7 & 20,6 & 1 & 2,9 & 0 & 0 \\
\hline No Answer & 14 & 41,2 & 22 & 64,7 & 26 & 76,5 \\
\hline
\end{tabular}

Based on Table 4, information is obtained that many students have difficulty or obstacles in solving the given problem. These obstacles can be seen from the mistakes in the answers given by students, students who worked on it but are not finished, and there are even students who did not do it at all. Each question worked on by 34 students. Therefore the percentage of the tests of students' creative thinking skills can be seen from the indicator that is only 29.4\% (Fluency); 35.3 (Flexibility); and $23.5 \%$ (Novelty). As for the samples of student work results (tests of creative thinking skill) of 3 questions given with the Correct but Incomplete (BL), Not Completed (TS), An Error Occurred (AK) types are as follows:

\section{Problem 1:}

This problem is to assess the aspect of flexibility because the methods used by students are more than two different methods. In this problem, students were asked to use at least 2 different ways to solve problems. 
A snack food company, the production process through two stages, namely the processing and packaging process. The processing cost follows the function of $Q 1(x)=20,000+50 x$ and the cost of the packaging process is $Q 2(x)=10,000+30 x$. with $x$ is the number of snack boxes. What is the total cost needed to make 800 boxes of snacks? (use two ways)

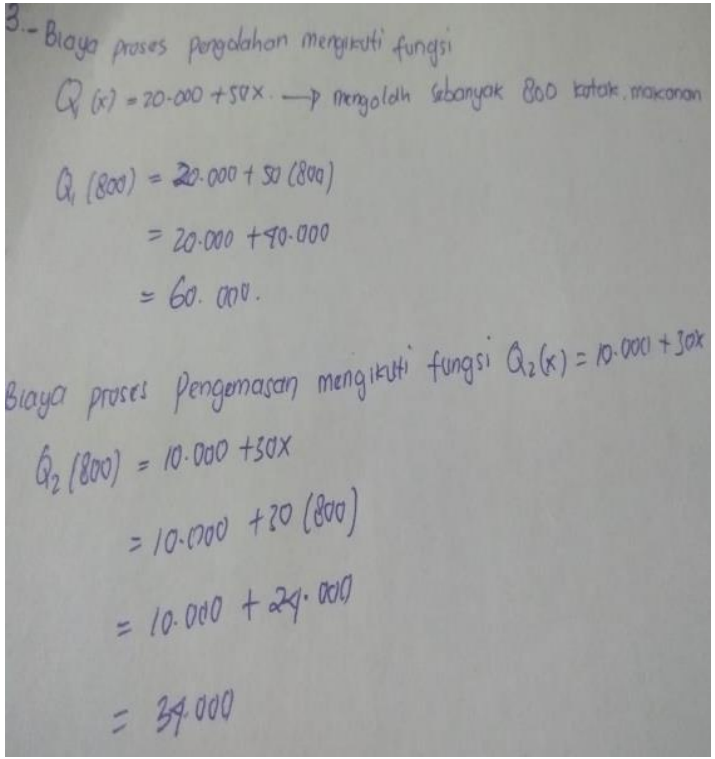

S1' comment:

The processing fee follows the function of $Q 1(x)=20,000$ $+50 x$ to process 800 boxes of snacks.

$Q_{1}(800)=20.000+50(800)$

$=20.000+40.000$

$=60.000$

So it costs Rp. 60,000, - for processing costs. While the cost of the packaging process follows the function $Q 2(x)=$ $10,000+30 x$, so to package 800 boxes of snacks:

$Q_{2}(800)=10.000+30 x$

$$
\begin{aligned}
& =10.000+30(800) \\
& =10.000+24.000 \\
& =34.000
\end{aligned}
$$

Figure 1. The S1' Comment

Figure 1 and the S1; Comment shows that the student can solve the given problem, but there is a misconception between students. Based on interviews conducted with students that they were only looking for Q1 and Q2, when in fact they need to find the total of Q1 and Q2. Then the student cannot reproduce or give the answer in a different way. Based on the interview that the S1 student did not have an indicator of flexibility, because the answers given by the student did not show the correct answer in different ways (several ways). Flexible thinking, if students are able to 1. Produce ideas, answers, or questions that are varied 2. Able to see the problem from a different perspective 3 . Look for many alternatives or different asepects 4. Able to change the way of thinking. Flexibility in problem-solving is defined as the skill of students to solve problems in the right various ways $[13,14]$.

Problem 2:

If it is known that the form of function is $f(x)=4 x+m$, determine the function formula that is formed if it is known $f(x)=\{x \mid 1 \leq x \leq 3 . x \in R\}$ where the function $x$ value is 2 !

This problem is to assess aspects of fluency because students might give various answers:

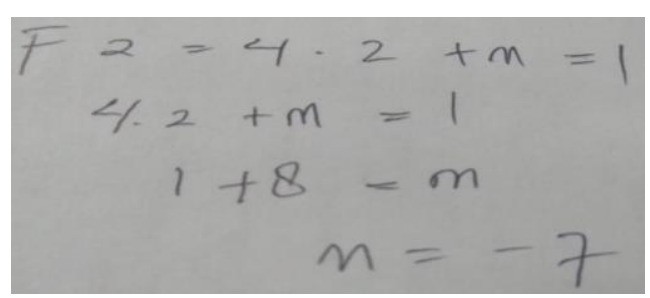

$$
\begin{aligned}
& \text { S2' comment: } \\
& f(2)=4 \cdot 2+m=1 \\
& 4 \cdot 2+m=1 \\
& 8+1=m \\
& m=-7
\end{aligned}
$$

Figure 2. The S2' Comment

Figure 2 and the S2; The comments show that the student can solve the given problem, but the S2 made a mistake and did not fit all over. Based on interviews conducted with students that the answers given by students is the only answer, there is no any other answers. Furthermore, when interviewing, one student still did not understand the work given, student did not concentrate when 
student was being asked why the results were $8+1=\mathrm{m}$ ? The answer is yes, but the student is still unaware that he is wrong, there is a mistake in the operation. Furthermore, when the student is asked to make another answer from the given problem, the student's replied that he cannot answer it. Based on the interview that the S2 students did not have indicators/aspects of fluency, because the student gave various answers. Fluent Thinking 1. Triggering a lot of ideas, answers, problem-solving or answers 2. Providing many ways or suggestions to do various things 3 . Always think of more than one answer [13] (Fluency) in problem-solving is defined as the skill of students to solve problems in the right various ways [14]. Some answers to problems might be called as various, if the answers appear different but follow a certain pattern, or have the same idea.

Problem 3:

Wheat raw material used per day is 7 tons. If the day the factory can produce $6500 \mathrm{~kg}$ Wheat flour. And flour produced in 3 stage using machine I, II, and III. Determine the function was the machine I and II machine functions that can satisfy the above conditions?

This problem assesses the novelty aspect because of some of the answers between students might be different.

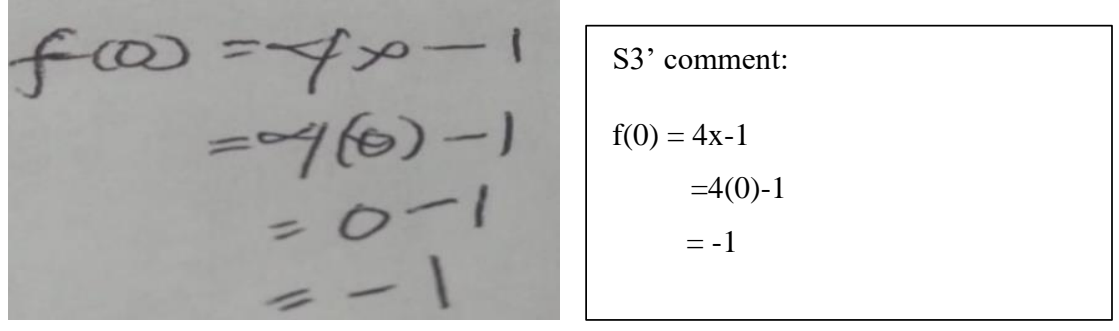

Figure 3. The S3' Comment

Figure 3 and the S3; Comment shows that the student can solve the given problem, but the S3 makes a mistake. Based on interviews conducted with students that the answers given by students is the only actual answers, there is no other answer. Furthermore, when interviewing, 1 student still did not understand the work given, students did not concentrate, when student was being asked how many points were obtained, S3 only answered -1 . Based on these interviews that the S3 did not have indicators/aspects of Novelty, because the students could not produce answers in their own way, language or ideas. Novelty in problem-solving is defined as the skill of students to answer problems that are new to students at the level of knowledge or the answers given have never been obtained before [14]. Novelty is the authenticity of ideas that is produced in giving a response to commands [15]. Interviews were conducted with students who had high, medium, and low motivation in learning mathematics, as well as students who could complete the questions (tests) of creative thinking skills. That was conducted to get more information about students' motivation to learn mathematics and the creative thinking skill. Although the creative thinking skill only shows in the right answer even though it is not complete.

\section{CONCLUSION}

Based on the results of the research, it can be concluded that student motivation is very influential on the creative thinking skill. It can be seen that students who have high motivation will be able to solve the given problems. Vice versa, if students have low motivation, they can not solve the given problems (the creative thinking skill is also low). It shows that the number of students in high school 
who have a learning motivation on the very high criteria is $0(0 \%)$ of 34 students; high criteria is 2 (5.9\%); moderate criteria is $11(32.4 \%)$; low criteria is $20(58.8 \%)$; and very low criteria is $1(2.94 \%)$. The average of high school student learning motivation towards mathematics is 50.9 , it means that students 'learning motivation in mathematics is still relatively low, as well as the students' creative thinking skill that is also in the low category.

\section{REFERENCES}

1. Effendi, Z., Novferma., \& Evtita. (2018). Pengembangan Buku Ajar Matematika Ekonomi Berbasis Problem Based Learning yang Mendukung Kemampuan HOTS Mahasiswa. Edumatica 08 (02):

2. Subchan, dkk. (2018). Buku Guru Matematika Kelas IX. Jakarta: Kementerian Pendidikan dan Kebudayaan

3. Santrock, J. (2011). Educational psychology (5th ed). New York: Mc Graw Hill Capay \& Magdin

4. Sariningsih, R. \& Herdiman, I. (2017). Mengembangkan Kemampuan Penalaran Statistik dan Berpikir kreatif Matematis Mahasiswa Melalui Pendekatan Open-Ended. Jurnal Riset Pendidikan Matematika 04(02): 239-246.

5. Johnson, E. B. (2010). Contextual teaching \& learning, (8th ed). (Terjemahan Ibnu Setiawan). Thousand Oaks, CA: Corwin Press, Inc. (Buku asli diterbitkan tahun 2009).

6. Sternberg R. J., (2006), Introduction, in Kaufman. J. C. and Sternberg R. J. (ed.), The International Handbook of Creativity, Cambridge: Cambridge University Press, pp. 1-10

7. Siswono, T. 2011. Level of Student's Creative Thinking in Clasroom Mathematics. Educational Research and Review 6(7).

8. Mullis, et al. (2011). Trends in international mathematics and science study. (2011). TIMSS 2011 international results in mathematics. Boston: Iternational Association for the Evaluation of Educational Achievement.

9. Rochani, S. (2016). Keefektifan pembelajaran matematika berbasis masalah dan penemuan terbimbing ditinjau dari hasil belajar kognitif kemampuan berpikir kreatif. Jurnal Riset Pendidikan Matematika 03(02): 273-283

10.Schunk, D.H., Pintrich., P.R., \& Mecee, J.L. (2010). Motivation in Education Theory, Research, and Applications(3rd ed.). New Jersey: Pearson Education

11. Fuqoha, Budiyono, \& Indriati. (2018). Motivation in mathematics learning. Pancaran Pendidikan FKIP 07 (01): 202-209.

12. Saifuddin, A. (2010). Penysunan skala psikologi. Yogyakarta: Pustaka Pelajar

13. William, F. (Ed) (1968). The Creativity at Home and in School, St. Paul M.N.: Mac Lester Creativity Project

14. Alimuddin, (2009). Menumbuh Kembangkan Kemampuan Berpikir Kreatif Siswa Melalui Tugas-Tugas Pemecahan Masalah. Fakultas MIPA, Universitas Negeri Yogyakarta, 16 Mei 2009

15. Tatag Yuli Eko Siswono, 2007. Penjenjangan Kemampuan Berpikir Kreatif dan Identifikasi Tahap Berpikir Kreatif siswa Dalam Memecahkan dan Mengajukan Masalah Matematika: Disertasi Pascasarjana UNESA Surabaya 